\title{
Impact of Sanitary Landfills on Urban Residential Property Value in Lagos State, Nigeria
}

\author{
O.A. AKINJARE \\ Department of Estate Management, School of Environmental Sciences \\ College of Science and Technology, Covenant University, Ota, Ogun State \\ Tel: 234(0)-803-8065-545Ｅ-mail: omoladeogah@yahoo.co.uk \\ C.A. AYEDUN (Ph.D) \\ Department of Estate Management, School of Environmental Sciences \\ College of Science and Technology, Covenant University, Ota, Ogun State \\ Tel: 234(0)-803-3900-681Ｅ-mail: caayedun@yahoo.com
}

A.O.OLUWATOBI

Department of Estate Management, School of Environmental Sciences

College of Science and Technology, Covenant University, Ota, Ogun State

Tel: 234(0)-803-8497-092 E-mail: wemimoos@yahoo.com

\section{O.C. IROHAM}

Department of Estate Management, School of Environmental Sciences

College of Science and Technology, Covenant University, Ota, Ogun State

Tel: 234(0) 803-6795-013 E-mail: emeka_iroham@yahoo.co.uk

Received: December 6, 2010

Accepted: January 10, 2011

doi:10.5539/jsd.v4n2p48

\begin{abstract}
Landfills have for long been generally thought to have diminutionary effect on residential property values. Various researches sparked off by this contention have proved contradictory in some instances. This study attempts to examine the impact of the four State established landfills on residential property values in Lagos State, each of varing sizes and having various degrees of contamination.

A total of 229, 2341 and 315 structured questionaires were administerd to Estate Surveyors and Valuers, residents within $1.2 \mathrm{~km}$ distance from four landfills and Lagos State Waste Management Agency (LAWMA) workers respectively and on the avearge, $78 \%$ were retrieved. Evaluation using linear regression function of data drawn from administered questionaires showed a slight evident of statistical significance indicating that all residential property values increased with distances away from landfill sites at an average of $6 \%$ for the four landfills.
\end{abstract}

Keywords: Landfills, Residential Property Value

\section{Introduction}

Waste generation is inevitable as long as life continually exist on planet earth. Man's activity encapsules the totality of deriving benefits from raw material while creating left over complexities. The nature of these complexities have been tied to factors as civilisation, improved living standards, economic and cultural attributes of man in his environment. With Nigeria being the most populous developing black nation in Africa with a teeming population of approximately 150 million people, its waste disposal and management programs cannot be over looked vis-a-vis its impact on the environment and predominantly, residential property values. Waste generation nationally is alarmingly on the increase with an estimated annual rate of about $0.5-0.7 \%$ and 
current figures ranging from 0.4 to 0.8 Ton /capital /annum. Complexity in waste is also increasing with biodegradable waste currently accounting for over $50 \%$. This amounts to an annual average approximately 50 milion tons per annum of waste burden on the nation with less than 10\% waste management capacity (Ossai, 2006).

This challenge has been accompanied by increased inefficency in waste disposal as domestical biodegradable wastes (paper, plastics, rags, food materials) in individual states of the federation are dumped and burnt in open areas beside individual dwelling and collectively as illegal dumpsites. With over thirty five percent (35\%) of the Nigerian population living in the cities vis-a-vis a growing urbanization rate of about $7 \%$ per annum and less than ten percent $(10 \%)$ of the city's population enjoying marginal waste management services, health and pollution problems have triggered the thrive of micro-organisms living in the environment. As individual states of the federation strive towards self sustainance financially, the tendency to industrialise has become pronounced. Industrialisation within states have sky rocketed the volume of urban waste and its complexity. Generated complex comprising heavy industrial wastes (abestos, cadmium and lead compounds, textile dyes) which require special disposal techniques in designated landfills are consciously disposed off indiscriminately by manufacturers into aquatic bodies and dumpsites via road side drainages and other conveyance channels.

Thomas (2000) notes that waste management which entails disposal is a labour and capital intensive function often consuming $20-50 \%$ of municipal operational budget. Therefore, the financial aspect of this constitutes a major hinderance for states in the federation with low federal allocations when viewed in light of total salary of the state's workforce and other overhead expenses. This invariably has fostered a partial or total breakdown of waste management in many towns and cities as failure to meet acceptable standards have had consequential injury on real estate and the environment (Ogedegbe and Oyedele 2006).

Lagos State being highly industrialised with a projected average population of between 12-18millon persons, utilises $20-25 \%$ of its funds on waste management. The creation of the 4 landfill sites in Gbagada, Olusosun, Abule-Egba, and Solous to a large extent fostered environmental aesthetics in major parts on the state, via improved property value while exposing neighbouring property owners and residents adjacent to these landfill sites to the detrimental environmental damage of these facilities. Apart from the environmental damage caused by landfills such as the accumulation of methane gas and possible ground water contamination, residents along landfill axis fear diminutionary effects of nearby landfills on their property value. This present study attempts to ascertain the empirical impact of these operational landfills on proximal residential property values in Lagos State.

\section{Previous Studies on Residential Property Value and Landfills}

According to the Microsoft Encarta dictionary (2009), value is defined as the worth, importance, or usefulness of something to somebody. It invariably implies that the value imposed on any item is relative to individuals and professionals in the light of its utility. Ogedegbe and Oyedele (2006) note that value implies the capacity to satisfy wants as wants are numerous.

The various professionals within the real estate industry each have diferent perspectives to the concept of value. To the Architect, value is aesthetic, to the Quantity Surveyor, it is cost implicative, to the Urban and Regional Planner, it is social value, Ratcliff (1978) and to the Estate Surveyor and Valuer, it is market value, Thorncroft (1975). Value by the layman is often expressed in money or other appropriate medium of exchange that is thought to be a fair exchange for something. It indicates the power of a commodity to command other commodities in exchange. The worth of such exchange is its market value. This provides the principal yardstick for measuring the worth of properties and other similar commodities. Though this is a subjective process, the Open Market Value (OMV) of a with-held interest on land has from time being famously established via this method. In a valuation bid, an estate surveyor and valuer estimates the value of an interest by assessing the possible monetary worth a potential buyer would place on a property with respect to its uniqueness, characteristics, finishes, immediate location and other environmental factors which could act as price facilitators or depressants.

Sanitary landfills have been found to be diminutive on residential properties as far back as 1971 in American literature. In one of the first studies of this type (Havlicek, Richardson and Davies 1971) found an increment house pricing by $\$ 0.61$ per foot of distance from landfills in Fort Wayne, Indiana. Similar results were obtained for landfills in Minnesota (Nelson et al 1992, 1997), Baltimore (Thayer et al 1992), Columbus, (Hite et al 2001), and Toronto (Lim and Missios 2003). Gamble et al. (1982) ascertained hedonic price regressions for residential property sales figures near a landfill in Boyertown, Pennsylvania. After spliting dataset and separate regressions estimated by year of sale, estimated coefficients for distance of residences from the landfill were not statistically significant at the $5 \%$ level. One of the estimated implicit prices was negative, implying higher prices closer to 
the landfill. This last result has been cited as evidence that modern landfills need not have negative impacts on property values (Cartee 1989, Parker 2003). However, the negative implicit price was estimated with very low precision due to the small sample size $(n=45)$. In a model that pooled observations across years, the estimated coefficient on distance of residences from the landfill was positive and significant at the $10 \%$ level, implying that the landfill actually depressed nearby property values.

Reichert et al (1992), in a hedonic regression analysis for homes located near a Cleveland landfill in Ohio found that the estimated Marginal Implicit Price (MIP) for distance was negative, implying homes had higher prices near the landfill. Furthermore, this estimated MIP was found to be statistically insignificant, with high sampling variability and an absence in relationship between proximity to the landfill and home prices was argued to be caused by an unmodelled heterogeneity in neighborhood quality. By the use of a smaller and more homogeneous study area, residential properties near the landfill were found to sell for $\$ 6000-\$ 8000$ less than homes farther away.

Bouvier et al (2000) estimated hedonic regressions for residential properties located near six landfills in central and western Massachusetts, two of which were functional during the study period. For the two landfills, the estimated Marginal Implicit Price (MIP) of distance was positive for one and negative for the other though, statistically the results were insignificant in both cases. The study therefore showed no statistical relationship between landfill proximity and the price of houses stating with evidence that landfills need not have negative impacts on nearby property values (Parker, 2003). This result sparked off a contention between the solid waste industry representatives and home owners. On the other hand, the estimated negative coefficient had a high sampling variability due to the small sample size of the study.

Bello (2005a) conducted a study on the effects of contamination on real estate property values in Lagos metropolis. Using rental and capital value gradients across three neighbourhoods (Oke Afa, Isolo; Abule Egba and Ojodu) close to refuse dumps, the study established that rental values of properties adjoinig these locations have been reduced by 37\% for blocks of flats at Oke Afa (Isolo) and 33\% in Ojodu for tenement apartments respectively. Similarly a reduction in capital values of vacant plots in the vicinities of Abule Egba and Ojodu ranged from $20 \%$ to $33 \%$ respectively.

In another study, Adewusi and Onifade (2006) focused on the effect of urban solid waste on physical environment and property transactions in Surulere Local Government Area of Lagos State. The study administered questionnaires randomly on residents and firms of estate agents to gather data on the subject matter. Data obtained were analysed using frequency tables and percentage ratings. The study found that rents paid on properties adjoining waste dumpsites were lower compared to similar properties further away and also, property transaction rates were very slow and unattractive as one approaches a dumpsite.

In the same vein, Bello (2007) used multiple regression analysis to determine the effect of waste dumpsites on property values in Olusosun neighbourhood at Ojota, Lagos State. The study found that property values increase with distance away from dumpsites. Also, Bello (2008) conducted a research on the willingness to pay for environmental amenities in Akure Nigeria. The study included environmental amenities such as waste water disposal, water and electricity supplies, neighbourhood roads and other locational services. The study used a two-staged hedonic model to examine the willingness to pay for better environmental services by residents of two neighbourhoods in Akure, Nigeria. He combined multiple regressions and predictive model to determine property values as a function of housing attributes and logistic model as willingness to pay. The study identified households' income, distance away from the refuse dump site and regularity of electricity supply as the major factors that influenced household's willingness to pay for better environmental services. The study recommended economic empowerment of the people, diligent consideration in the location of dumpsites and adoption of Public-Private Initiative in the provision of public infrastructure. The study established that real estate values are readily influenced by residents williongness to pay for both structural as well as neighbourhood characteristics where the real estate is located. However, Bello (2008) failed to relate property values with distance from the waste dump site as an environmental disamenity. This present study fills this gap.

Bello (2009) carried out a study on the effects of waste dump sites on proximate property values in Lagos, Nigeria using three dump sites located at Olusosun, Abule Egba and Solous adopting $1 \mathrm{~km}$ distance measurement to assess the effects of the dumpsite on the neighbourhoods. The research sampled 334 residents from the three waste dump sites and 107 Estate Surveying and Valuation firms in metropolitan Lagos. The study was in the main to measure the effect of waste dump on property values and to develop an appropriate valuation methodology to carry out valuation of properties affected by waste dump sites. A combination of valuation methodologies was adopted such as Paired Sales Analysis, Contingent Valuation Analysis, Option Pricing Model 
and Hedonic Approach. The study found that there was a weak linear relationship between rental value and satisfaction of occupants in the neighbourhood of the waste dumps.

Several other studies have established empirical relationships between residential property values and proximity to sanitary landfills. Some of these studies have estimated a hedonic price function, where the price of a residential property is regressed on the characteristics and the proximity of the landfill to the house. Many of these studies also have identified that houses located proximal landfills command lower prices than similar houses located farther away. One of such widely-cited study is that of Nelson et al (1992), which found diminutions in residential property values within 2 miles of a particular landfill with an average property value gradient of $6.2 \%$ per mile. Notably, many of these studies were based on relatively small samples of house sales, so that the sampling variability in the estimated relationship between proximity and house price was high. It is possible that the landfills studied had negative impacts on nearby property values but that the relationship could not be statistically identified due to small sample sizes. There is yet to be a large-sample sized study that conclusively demonstrates small or non-existent property value impacts from a landfill. This current study again fills this gap in literature.

The purpose of this study is to complement the stock of empirical estimates on the impact of a landfill on nearby property values by using a larger sample size of 2341 homes. A hedonically derived regression function is utilised in analysing estimates for the regions harbouring the four various landfills that differ in size and prominence on the landscape. Results show that the four landfills differ in their impact on nearby property values. While two of the three landfills have statistically significant negative impacts on nearby property values, the smallest, least prominent landfill does not.

\section{Data Collection and Research methods}

Primary data were collected through questionnaires distributed to Estate Surveyors and Valuers, residents within $1.2 \mathrm{~km}$ of the four landfills as well workers of Lagos State Waste Management Agency (LAWMA). The survey took every third house within $1.2 \mathrm{~km}$ of each of the 4 landfill sites. The responses are as follows; Gbagada -(848), Olusosun -(674), Abule-Egba -(422) and Solous -(397). Inclusively, 229 Estate Surveyors and 315 Lagos State Waste Management Agency officials returned questionnaires administered to them. The survey recorded an average response rate of $78 \%$ and collated data were analysed using a re-developed linear regression function.

\section{Data Analysis and Operationalisation of Variables}

In the course of this study, certain variables were operationalised in order to achieve the goal of the study. The dependent variable in this study is Property Value (PV) while twenty four other independent variable were regressors in the research. The hedonic model involves regressing observed asking prices for houses against those attributes of houses perceived to be the determinants of the asking price. However, while utility theory is not sufficiently well developed to identify the precise definition of all the variables, a wide range of statistical studies by Kohlhase (1991) have documented the importance of a consistent set of housing characteristics efficiently employed in hedonic appraisal methods. The variables included in the current model were drawn from recent empirical studies and generally conform to current appraisal practice. Implicitly, the set of regressors adopted in the model for the hedonic price function include the following continuous variables defined as:

PRICE $=$ price of property wihin $1.2 \mathrm{~km}$ radius from the landfill

TYPE $=$ type of property

FINISHING $=$ standard of finishing

PLOT SIZE $=$ area of land in square meters

BDRM SIZE $=$ size of bedroom in square meters

$($ LIVRMS $)=$ total square meter of living room

TLTS $=$ total number of toilets

TLTS SIZE $=$ area of toilet in square meters

BTRMS $=$ total number of bathrooms

KITCHEN $=$ availability of kitchen

TIME = housing transactions recorded for a period of five years (2003-2007)

$\mathbf{A G E}=$ age of the house in years 
SALE YR = year of sale

NBHQUAL = neighbouhood quality

DIST LDF = distance from the landfill measured in kilometer

DIST CBD = distance of the landfill from the Central Business District

SOLD = number of properties sold by Estate Surveying Firms within the period

DIST EXPR = distance of property from the express way.

A number of housing amenities were included as dummy variables in the model and are indicated with ' $\mathbf{I}$ ' and ' $\mathrm{O}$ ' for their absence. These variable include (AIRCON), availability of water heater (W/HEATER), availability of a garage (GARAGE), availability of a neighbourhood school, good drainage network (DRAINAGE) and accessibility of the location (ACCESS). These set of variables were entered into the database and analysed using regression analysis. Record of the open market value of residential properties were retrieved from Estate Surveying firms for the period of 2003-2007.

The study made use of Pearson's product moment correlation coefficient, concentric rings with measurements based on a $300 \mathrm{~m}$ interval up to $1200 \mathrm{~m}$ and a derived regression model $\mathrm{PV}_{\mathrm{di}}=\alpha_{\mathrm{Li}}+\beta_{\mathrm{i}} \mathrm{H}+\beta_{\mathrm{i}} \mathrm{N}+\mathrm{Y}_{\mathrm{i}}+\epsilon$ for analysis. Results were generated for each of the four landfills in nairage value term based on the standard hedonic model developed by Rosen (1974), Freeman (1979, 2003) and Reichert (1991) the linear regression function was derived thus:

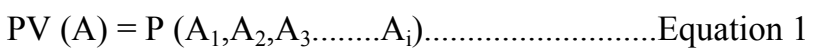

Where

$\mathrm{PV}(\mathrm{A})$ is the house sales price and $\left(\mathrm{A}_{1}, \mathrm{~A}_{2}, \mathrm{~A}_{3} \ldots \mathrm{A}_{\mathrm{i}}\right)$ are the various attributes.

For studying the impact of landfills on housing values, the linear form of the regression model is as restated as:$\mathrm{PV}=\alpha+\beta_{1} \mathrm{X}_{1}+\beta_{2} \mathrm{X}_{2}+\beta_{3} \mathrm{X}_{3}+\ldots \ldots \ldots .+\beta_{\mathrm{n}} \mathrm{X}_{\mathrm{n}+\beta \mathrm{mLF}+\mathrm{e} \ldots \ldots \ldots \text { Equation } 2}$

Where

$\mathrm{PV}=\mathrm{a}$ vector of observed sales prices,

$\alpha=$ is the intercept that summarises the impact of variables not included in the model;

$\beta_{1,,,,,,, \beta n}=$ are the marginal value of certain housing characteristics, such as size or age

$\beta_{\mathrm{m}}=$ are the marginal impact of distance to the landfill measured in kilometers.

$\mathrm{X}_{1} \ldots \ldots . \mathrm{X}_{\mathrm{n}}=$ non landfill factors that could affect values

$\mathrm{LF}=$ landfill and

$\mathrm{e}=$ random error.

By incorporating the property value factor while adopting distance at point $\left(\mathrm{d}_{\mathrm{i}}\right)$ as a dependent variable, a new form of hedonic equation is developed and expressed as:

$P V_{d i}=\alpha_{L i}+\beta_{i} H+\beta_{i} \mathrm{~N}+\mathrm{Y}_{\mathrm{i}}+\mathrm{C}$ equation 3

Where,

$P V_{d i}=$ The sales price of the "ith" house at a distance $d_{i}$

$\alpha_{\dot{L} i}=$ mean value of a property in landfill areas is treated as the intercept in the regression equation

$\beta_{\mathrm{i}} \mathrm{H}=\mathrm{a}$ vector of continuous non environmental property characteristics such as building size, age, number of bedrooms

$\beta_{\mathrm{i}} \mathrm{N}=$ a vector of discrete variables including the neighbourhood status of the property as at the time of the sale. Eg quality of the neigbhbourhood school.

$\mathrm{y}_{\mathrm{i}}=\mathrm{a}$ vector of discrete terms indicating the property's year of sale, to capture effects of landfills due to market conditions overtime,

$\mathrm{E}=$ indeterminate Stochastic random error term factored into the derivation of the intercept $\alpha_{\mathrm{L} i}$ which is not an absolute value.

Table 4.1 shows the descriptive statistics of the variables and the result of regression analysis. The coefficient of multiple determination was 0.526 and that of the co efficient of multiple correlation was 0.761 , while standard 
error of multiple estimate was 2576.29 . The figure of 0.526 was the aggregation of the individual level of inputs of value contributed by all the variables to the overall value of residential properties around Gbagada landfill. Also, the coefficient of multiple correlation was a measure of the relationship or association existing amongst the variables in which ' $r$ ' must fall between -1 and $+1(-\leq r \leq)$. In case of Gbagada landfill, $\mathbf{r}=0.761$ which depicts a highly positive correlation amongst variables. The standard error of values for the values of all the residential properties in Gbagada was $5 \%$ which was within acceptable region $(C<0.05)$.

The five most significant variables for Gbagada landfill were year of sale (SALE YR): 3.59; number of toilets (TLTS): 3.59; number of bathrooms (BTRMS): 3.57: plot size (PLOT SIZE): 3.42 and type of property (TYPE): 3.35 . These five significant variables had an estimated mean property value of $=\mathrm{N}=4637$ which represented $36 \%$ of the property value for Gbagada. Distance from the landfill (DIST LFL) was positively significant with an estimated value of $=\mathrm{N}=515$. The amount represented $4 \%$ property value increase away from the landfill site.

Table 4.2 shows the descriptive statistics of the variables and the result of regression analysis. The coefficient of multiple determination was 0.681 and that of co efficient of multiple correlation was 0.601 , while the standard error of multiple estimate was 2 637.26. the standard error value was within the acceptable region $(\epsilon<0.05)$. The most pronounced variable was the base price that indicated $=\mathrm{N}=13.187$ million as the mean value with a standard deviation of 2.568. The 5 most significant variables for Olusosun landfill were plot size (PLOT SIZE): 3.78; type of property (TYPE): 3.67; number of bathrooms (BTRMS): 3.49: year of sale (SALE YR):3.46 and number of toilets (TLTS): 3.24. The five significant variables had an estimated mean property value $=\mathrm{N}=5275$ which represented $40 \%$ of the property value for Olusosun. Distance from the landfill (DIST LFL) was positively significant with an estimated value of $=\mathrm{N}=971$. The amount represented $6 \%$ property value increase away from the landfill site.

Table 4.3 shows the descriptive statistics of the variables and the result of regression analysis. The coefficient of multiple determination was 0.546 and that of co efficient of multiple correlation was 0.976 , while the standard error of multiple estimate was 2322.57 . The standard error value was within the acceptable region $(€<0.05)$. Also, the base price was $=\mathrm{N}=11.613$ million which was the mean value with a standard deviation of 2.737 . The 5 most prominent variables for Olusosun landfill were number of bedrooms (BDRMS): 3.62; type of property (TYPE): 3.57; plot size (PLOT SIZE): 3.52; number of toilets (TLTS): 3.24 and year of sale (SALE YR): 3.07. The five significant variables had an estimated mean property value $=\mathrm{N}=3832$ which represented $33 \%$ of the property value for Abule Egba. Distance from the landfill (DIST LFL) was positively significant with an estimated value of $=\mathrm{N}=670$. The amount represented $6 \%$ property value increase away from the landfill site.

Table 4.4 shows the descriptive statistics of the variables and the result of regression analysis. The coefficient of multiple determination was 0.623 and that of co efficient of multiple correlation was 0.714 , while the standard error of multiple estimate was 1906.29 . The standard error value was within the acceptable region $(€<0.05)$. Also, the base price was $=\mathrm{N}=9531$ million which was the mean value with a standard deviation of 3.196. The 5 most prominent variables for Solous landfill were distance from the landfill (DIST LFL): 2.98; type of property (TYPE): 2.93; plot size (PLOT SIZE): 2.79; year of sale (SALE YR): 2.78; and number of properties sold (SOLD): 2.53. The five significant variables had an estimated mean property value $=\mathrm{N}=2853$ which represented $30 \%$ of the property value for Solous. Distance from the landfill (DIST LFL) was positively significant with an estimated value of $=\mathrm{N}=620$. The amount represented $7 \%$ property value increase away from the landfill site.

\subsection{Summary of the Significant Variables Across the Four Landfill Sites.}

Table 4.5 sumarizes the five most significant variables that influenced residential property values in each of the landfill sites. From the table, distance from landfills was a common factor at Gbagada and Solous while plot size was a significant factor of value in all the landfill locations. The size of bedrooms was highly significant to residents at Abule Egba while the number of bathrooms available in the property was a crucial factor of value at Olusosun in Ojota. Also, plot sizes, year of sale were considered as significant factors of value in all the landfill sites. However, the number of properties sold by Estate Surveyors at Gbagada and Solous formed a good basis for ascertaining property value trends in those locations. At Olusosun and Abule Egba, the provision of toilets in residential properties was a good basis of value appreciation as observed in the table.

\subsection{Estimated Property Value Differences From Landfill Sites}

Two major conclusions can be drawn from the above analysis- there was a derived property value increase for each of the landfill as well as the percentage property value increase as one moves away from the landfill. These two figures (table 4.6) had different meanings within each landfill neighbourhood. A keen observation from table 
4.6 suggests that Gbagada landfill neighbourhood had the least percentage property value (4\%) away from the landfill as well as the lowest estimated neighbourhood property value appreciation of $=\mathrm{N}=515000$. This could be attributed to the swampy nature of the site from Oworonshoki end through Anthony Village. With the exception of Phases 1 and 2 of Gbagada Housing Estate, the strip of land between Pedro and Anthony to the left flank is swampy. Apart from high construction cost of building in swampy areas, the annual maintenance cost of buildngs within the swampy zones might be enormous. These two reasons accounted for the low rating obtained on Gbagada landfill neighbourhood.

Second, Olusosun and Abule Egba landfill sites recorded equal 6\% residential property value increase. The two locations have certain common neighbourhood characteristics (within firm soil; commercial nerve center and along major expressway). While Abule Egba houses Katagora International Market, Oke Odo food market and Oko Oba abbatoirs, Olusosun in Ojota accomodates Ojota motor parks, large retail shops, industries such as SmithklineBeecham Pharmaceuticals and Philips Electronics. These characteristics led to a high influx of people to the two landfill neighbourhoods hence the $=\mathrm{N}=791000$ and $=\mathrm{N}=670000$ estimated neighbourhood property value appreciation recorded respectively for Abule Egba and Olusosun neighbourhoods.

Third, Solous landfill neighbourhood attracted the highest (7\%) property value appreciation away from landfill. This maybe due to the influx of staff and students of the Lagos State University, Ojo into the neighbourhood for residential accommodation. The firm nature of the Solous landfill neighbourhood soil favours normal construction costs as against what obtains in waterlogged Gbagada landfill neighbourhood. The firm nature of the soil and higher demand for residential accommodation in Solous landfill neighbourhood property of $=\mathrm{N}=620$ 000 as against $=\mathrm{N}=515000$ found in Gbagada. Comparing average value per kilometer and also percentage increase, the current study has a calculated average value of $=\mathrm{N}=2168$ per $1.2 \mathrm{~km}$ and an average percentage increase in property value of $6 \%$ for $1.2 \mathrm{~km}$ away from landfill.

\section{Findings}

The study showed that nine (9) major areas of risk elements were identified by both residents and and estate surveyors. However, the six most prominent were noted. Truck traffic, air pollution and odour, stigma, blowing trash and noise pollution which were perceived to be of high impact of landfill on residential property values by residents. Estate Surveyors and Valuers identified poisonous odour, air pollution, stigma, truck traffic, insects and pest and noise pollution as high impact factors that may affect residential property values. Perceived health hazards expressed by residents were further confirmed during indepth interviews conducted with resident associations.

\section{Recommendations}

The Lagos State Waste Management Agency (LAWMA) should acquire modern compacting machinery for compacting landfills so as to reduce methane gas leading to air pollution that often constitute health hazards. Solous, Abule Egba and Olusosun were not pleasant to sight and thus an urgent need for action plans and education by LAWMA in order to improve the monitoring, control and projection of solid waste expected in the nearest future. There is the need to expand recycling programmes through modern methods with a view of turning waste to wealth in metropolitan Lagos.

Finally the support of the private sector and NGOs is also required most especially in the area of organising maintenance workshops and enlightenment programs which should include the grassroots participation and input. The introduction of custom built vehicles for waste collection and disposal is highly commendable as this has drastically reduced the volume of trash thrown along truck routes. The same customised truck vehicles should be made mandatory for the private sector collaborating with Government's effort. Also, Government should improve on the control of truck traffic creating traffic jam along their routes.

\section{Conclusions}

This current study has established that there is a negative correlation between landfills and residential property values. The study has also brought into focus those factors that hitherto might not have received much attention. It is therefore, hoped that if the Lagos State Government is able to look into most of the recommended solutions the quality of the environment will be enhanced and this will positively affect residential property values.

\section{References}

Adewusi, A.O \& Onifade. F. A. (2006). The effects of urban solid waste on physical environment and property transactions in Surulere local government area of Lagos state. Journal of Landuse and Development Studies, 2 (1), 71-90. 
Bello, M.O. (2005a). Environmental contamination and property values In: E Okoko, V.A Adekunle and S.A Adeduntan, (Ed.), Environmental Sustainability and Conservation in Nigeria, Federal University of Technology, Akure, Nigeria, 220-224.

Bello.V.A. (2007). The effects of Ojota waste dump site on surrounding property values in Lagos metropolis. Journal Of Environmental Conservation And Research, 1, (1\&2) 136-142.

Bello, M.O \& Bello V.A. (2008). Willingness to pay for better environmental services: Evidence from the Nigerian real estate market. Journal of African Real Estate Research, 1(1), 19-27.

Bello, V.A. (2009). The effects of waste dump sites on proximate property values in lagos Nigeria, (Unpublished Ph.D Dessert) Federal University of Technology, Akure, Nigeria.

Bouvier, R.A., J.M. Halstead, K.S. Conway \& A.B Manalo. (2000). The effect of landfills on rural residential property values: Some empirical analysis. Journal of Regional Analysis and Policy, 30(2); 23-37.

Cartee.C.P. (1989). A review of sanitary landfill impacts on property values. Real Estate Appraiser and Analyst, pp. 43-47 (Spring 1989).

Freeman, A. Myrick III. (1979). Hedonic prices, property values and measuring environmental benefits: A survey of the issues. Scandinavian Journal of Economics, 81(2): 154-173.

Freeman III, A.M. (1993). The measurement of environmental and resource values, theory and methods. Resources for the future, Washington, D.C.

Gamble, H. B., R. H. Downing, J. S. Shortle \& D. J. Epp. (1982). Effects of solid waste disposal sites on community development and residential property values. Final report for the bureau of solid waste management (Department of Environmental Resources, Commonwealth of Pennsylvania).

Havlicek, Joseph Jr., Robert Richardson \& Lloyd Davies. (1971). Measuring the impacts of solid waste disposal site location on property values. Urban Journal of Real Estate Research, 7(3): 297-314.

Hite, D., W. Chern, F. Hitzusen, \& A. Randall. (2001). Property value impacts of an environmental disamenity: The case of landfills. Journal of Real Estate Finance and Economics, 22(2/3), 185-202.

Kohlhase, J. (1991). The impact of toxic waste sites on housing values, Journal of Urban Economics, 30, 1-26.

Lim, J. S. \& P. Missios. (2003). Does size really matter? Landfill scale impacts on property values. Unpublished working paper, Department of Economics, Ryerson University,Toronto.

Microsoft Encarta Dictionary. (2009). (C) 1993-2008 Microsoft Corporation.

Nelson, Arthur C., John Genereux \& Michelle Genereux. (1992). Price effects of landfills on house values. Land Economics. 68(4): 359-365.

Nelson, A.C., J. Genereux, \& M.M. Genereux. (1997). Price effects of landfills on different house value strata. Journal of Urban Planning and Development, 123( 3):59-67.

Ogedegbe \& Oyedele. (2006). Effect of waste management on property values in Ibadan Nigeria. Journal of Land Use and Development Studies, Vol. 2, No. 1, 2006.

Ossai, R.M. (2006). Moving solid waste management into the 21st century in Nigeria. Presented at the 6th National Council on Environment Meeting held at Katsina State Secretariat, Katsina 13th- 17th, November, 2006.

Parker, B.J. (2003). Solid waste landfills and residential property values. White Paper, National Solid Wastes Management Association, Washington, DC. 6 pp.

Reichert, Alan K. (1991). The impact of landfills on residential property values. Cleveland, OH: Cleveland State University.

Reichert, A.K., M. Small, \& S. Mohanty. (1992). The impact of landfills on residential property values. The Journal of Real Estate Research, 7(3), 297-314.

Rosen, S. (1974). Hedonic prices and implicit markets: Product differentiation in pure competition. Journal of Political Economy, 82, 34-55.

Thayer, M., H. Albers, \& M. Ramatian. (1992). The benefits of reducing exposure to waste disposal sites: A hedonic housing value approach. The Journal of Real Estate Research, 7(3), 265-282.

Thomas. L. (2000). Brief history of solid waste management. Written for The California Department of Health Services.

Thorncroft. M. (1975). Principles of estate management, (1st ed.). London: The Estate Gazette Ltd. 
Table 4.1 Gbagada Landfill Regression Results -Distance Variable

The linear regression analysis for Abule Egba landfill is as contained below

\begin{tabular}{|l|l|l|l|}
\hline Variables & Mean & Std Dev & Std Error \\
\hline PRICE (N'000) & 12881.43 & 1.94443 & 0.006944 \\
\hline SOLD & 2.31 & 0.84918 & 0.003033 \\
\hline TYPE & 3.35 & 1.8333 & 0.006548 \\
\hline FINISHING & 1.47 & 0.6106 & 0.002181 \\
\hline PLOT SIZE & 3.42 & 1.06534 & 0.003805 \\
\hline BDRM SIZE & 2.54 & 0.85776 & 0.003063 \\
\hline LIVRMS & 1.78 & 0.74644 & 0.002666 \\
\hline AREA & 2.29 & 0.64031 & 0.002287 \\
\hline TLTS & 3.59 & 0.21518 & 0.004340 \\
\hline TLT SIZE & 1.86 & 0.66697 & 0.002382 \\
\hline BTRMS & 3.57 & 0.16563 & 0.004163 \\
\hline W/HEATER & 1.36 & 0.48242 & 0.001723 \\
\hline GARAGE & 1.29 & 0.45605 & 0.001629 \\
\hline KITCHEN & 1.08 & 0.27266 & 0.000974 \\
\hline SWM POOL & 1.85 & 0.35887 & 0.001282 \\
\hline AGE & 2.29 & 0.7693 & 0.002748 \\
\hline NBH QUAL & 1.57 & 0.68542 & 0.002448 \\
\hline ACCESS & 1.01 & 0.01002 & 0.000036 \\
\hline SCHOOL & 1.26 & 0.44084 & 0.001574 \\
\hline DRAINAGE & 1.16 & 0.36845 & 0.001316 \\
\hline DIST CBD & 1.65 & 0.57516 & 0.002054 \\
\hline SALE YR & 3.59 & 0.25606 & 0.004486 \\
\hline DIST LDF & 2.3 & 0.87986 & 0.003142 \\
\hline AIRCON & 1.4 & 0.49264 & 0.001759 \\
\hline DIST EXPR & 1.2667 & 0.44469 & 0.001588 \\
\hline & & & \\
\hline
\end{tabular}

Regression Analysis:

Co efficient of multiple determination

0.526

Co efficient of multiple correlation

0.761

Standard error of multiple estimate

2576.29 
Table 4.2 Olusosun Landfill Regression Results -Distance Variable.

The linear regression analysis for Olusosun landfill is as contained below.

\begin{tabular}{|l|l|l|l|}
\hline Variables & Mean & Std Dev & Std Error \\
\hline PRICE (N'000) & 13186.32 & 2.567966 & 0.007337 \\
\hline SOLD & 2.45 & 1.16563 & 0.003330 \\
\hline TYPE & 3.67 & 0.48242 & 0.001378 \\
\hline FINISHING & 1.52 & 0.45605 & 0.001303 \\
\hline PLOT SIZE & 3.78 & 0.27266 & 0.000779 \\
\hline BDRM SIZE & 2.75 & 0.35887 & 0.001025 \\
\hline LIVRMS & 1.56 & 0.57516 & 0.001643 \\
\hline AREA & 2.36 & 0.25606 & 0.003589 \\
\hline TLTS & 3.24 & 0.87986 & 0.002514 \\
\hline TLT SIZE & 1.73 & 0.49264 & 0.001408 \\
\hline BTRMS & 3.49 & 0.44469 & 0.001271 \\
\hline W/HEATER & 1.24 & 0.48242 & 0.001378 \\
\hline GARAGE & 1.37 & 0.45605 & 0.001303 \\
\hline KITCHEN & 1.13 & 0.27266 & 0.000779 \\
\hline SWM POOL & 1.96 & 0.84918 & 0.002426 \\
\hline AGE & 2.38 & 1.53403 & 0.004383 \\
\hline NBH QUAL & 2.45 & 0.45025 & 0.001286 \\
\hline ACCESS & 1.45 & 1.06534 & 0.003044 \\
\hline SCHOOL & 1.26 & 0.85776 & 0.002451 \\
\hline DRAINAGE & 1.25 & 0.74644 & 0.002133 \\
\hline DIST CBD & 1.61 & 0.64031 & 0.001829 \\
\hline SALE YR & 3.46 & 0.48242 & 0.001378 \\
\hline DIST LDF & 2.72 & 0.45605 & 0.001303 \\
\hline AIRCON & 1.03 & 0.27266 & 0.000779 \\
\hline DIST EXPR & 1.32 & 0.35427 & 0.001012 \\
\hline
\end{tabular}

Regression Analysis:

Co efficient of multiple determination $\quad 0.681$

Co efficient of multiple correlation $\quad 0.601$

Standard error of multiple estimate $\quad 2637.26$ 
Table 4.3 Abule Egba Landfill Regression Results -Distance Variable.

The linear regression analysis for Abule Egba landfill is as contained below.

\begin{tabular}{|l|l|l|l|}
\hline Variables & Mean & Std Dev & Std Error \\
\hline PRICE (N'000) & 11612.86 & 2.73708 & 0.006843 \\
\hline SOLD & 2.52 & 0.44084 & 0.001102 \\
\hline TYPE & 3.57 & 0.36845 & 0.000921 \\
\hline FINISHING & 1.65 & 0.57516 & 0.001438 \\
\hline PLOT SIZE & 3.52 & 0.48242 & 0.001206 \\
\hline BDRM SIZE & 2.74 & 0.45605 & 0.001140 \\
\hline LIVRMS & 1.56 & 0.27266 & 0.000682 \\
\hline AREA & 2.36 & 0.35887 & 0.000897 \\
\hline TLTS & 3.24 & 0.21518 & 0.003038 \\
\hline TLT SIZE & 1.35 & 0.66697 & 0.001667 \\
\hline BTRMS & 3.62 & 0.16563 & 0.002914 \\
\hline W/HEATER & 1.47 & 0.48242 & 0.001206 \\
\hline GARAGE & 1.32 & 0.49264 & 0.001232 \\
\hline KITCHEN & 1.18 & 0.44469 & 0.001112 \\
\hline SWM POOL & 1.93 & 0.48242 & 0.001206 \\
\hline AGE & 2.64 & 1.45605 & 0.001140 \\
\hline NBH QUAL & 1.68 & 0.68542 & 0.001714 \\
\hline ACCESS & 1.26 & 0.01002 & 0.000025 \\
\hline SCHOOL & 1.42 & 0.44084 & 0.001102 \\
\hline DRAINAGE & 1.28 & 1.16563 & 0.002914 \\
\hline DIST CBD & 2.41 & 0.48242 & 0.001206 \\
\hline SALE YR & 3.07 & 0.45605 & 0.001140 \\
\hline DIST LDF & 2.57 & 0.27266 & 0.000682 \\
\hline AIRCON & 1.37 & 0.35887 & 0.000897 \\
\hline DIST EXPR & 1.52 & 0.01002 & 0.000025 \\
\hline
\end{tabular}

Regression Analysis:

Co efficient of multiple determination $\quad 0.546$

Co efficient of multiple correlation $\quad 0.976$

Standard error of multiple estimate $\quad 2322.57$ 
Table 4.4 Solous Landfill Regression Results -Distance Variable

The linear regression analysis for Solous landfill is as contained below.

\begin{tabular}{|l|l|l|l|}
\hline Variables & Mean & Std Dev & Std Error \\
\hline $\begin{array}{l}\text { PRICE } \\
\text { (N'000) }\end{array}$ & 9531.43 & 3.195747 & 0.010652 \\
\hline SOLD & 2.53 & 0.48242 & 0.001608 \\
\hline TYPE & 2.93 & 0.45605 & 0.001520 \\
\hline FINISHING & 1.46 & 0.27266 & 0.000909 \\
\hline PLOT SIZE & 2.79 & 0.66697 & 0.002223 \\
\hline BDRM SIZE & 2.03 & 1.16563 & 0.003885 \\
\hline LIVRMS & 1.57 & 0.48242 & 0.001608 \\
\hline AREA & 2.37 & 0.49264 & 0.001642 \\
\hline TLTS & 2.62 & 0.27266 & 0.000909 \\
\hline TLT SIZE & 1.02 & 0.35887 & 0.001196 \\
\hline BTRMS & 2.54 & 1.21518 & 0.004051 \\
\hline W/HEATER & 0.98 & 0.66697 & 0.002223 \\
\hline GARAGE & 1.03 & 1.16563 & 0.003885 \\
\hline KITCHEN & 1.35 & 0.48242 & 0.001608 \\
\hline SWM POOL & 0.56 & 0.45605 & 0.001520 \\
\hline AGE & 2.04 & 0.35887 & 0.001196 \\
\hline NBH QUAL & 1.76 & 1.21518 & 0.004051 \\
\hline ACCESS & 2.32 & 0.66697 & 0.002223 \\
\hline SCHOOL & 1.43 & 0.35887 & 0.001196 \\
\hline DRAINAGE & 1.07 & 1.21518 & 0.004051 \\
\hline DIST CBD & 1.25 & 0.66697 & 0.002223 \\
\hline SALE YR & 2.78 & 0.35887 & 0.001196 \\
\hline DIST LDF & 2.98 & 0.21518 & 0.004051 \\
\hline AIRCON & 1.07 & 0.66697 & 0.002223 \\
\hline DIST EXPR & 2.38 & 1.16563 & 0.003885 \\
\hline & & & \\
\hline
\end{tabular}

Regression Analysis:

Co efficient of multiple determination

0.623

Co efficient of multiple correlation 0.714

Standard error of multiple estimate

1906.29 
Table 4.5 Five Significant Variables in each of the Four Landfill Sites.

\begin{tabular}{|c|c|c|c|c|c|}
\hline \multirow{2}{*}{$\begin{array}{l}\text { Landfill Sites } \\
\text { Gbagada }\end{array}$} & \multicolumn{5}{|c|}{$\begin{array}{l}\text { Significant Variables } \quad \text { Influencing Value } \\
\end{array}$} \\
\hline & DIST LFL (2.98) & $\begin{array}{l}\text { TYPE } \\
(2.93)\end{array}$ & $\begin{array}{ll}\text { PLOT } & \text { SIZE } \\
(2.79) & \end{array}$ & $\begin{array}{ll}\text { SALE } & \text { YR } \\
(2.78) & \end{array}$ & $\begin{array}{l}\text { SOLD } \\
(2.53)\end{array}$ \\
\hline Olososun (Ojota) & BTRMS (3.49) & $\begin{array}{l}\text { TYPE } \\
(3.67)\end{array}$ & $\begin{array}{ll}\text { PLOT } & \text { SIZE } \\
(3.78) & \end{array}$ & $\begin{array}{ll}\text { SALE } & \text { YR } \\
(3.46) & \end{array}$ & $\begin{array}{l}\text { TLTS } \\
(3.24)\end{array}$ \\
\hline Abule Egba & BDRMS (3.62) & $\begin{array}{l}\text { TYPE } \\
(3.57)\end{array}$ & $\begin{array}{ll}\text { PLOT } & \text { SIZE } \\
(3.52) & \end{array}$ & $\begin{array}{ll}\text { SALE } & \text { YR } \\
(3.07) & \end{array}$ & $\begin{array}{l}\text { TLTS } \\
(3.24)\end{array}$ \\
\hline Solous (Igando) & DIST LFL (2.98) & $\begin{array}{l}\text { TYPE } \\
(2.93)\end{array}$ & $\begin{array}{ll}\text { PLOT } & \text { SIZE } \\
(2.79) & \end{array}$ & $\begin{array}{ll}\text { SALE } & \text { YR } \\
(2.78) & \end{array}$ & $\begin{array}{l}\text { SOLD } \\
(2.53)\end{array}$ \\
\hline
\end{tabular}

Field Survey, 2010

Table 4.6 Estimated Property Value Increases From Landfill Sites.

\begin{tabular}{|l|l|l|}
\hline Landfill Sites & $\begin{array}{l}\text { Estimated Neighbourhood } \\
\text { Property Value (000) }\end{array}$ & $\begin{array}{l}\text { \% Property Value Appreciation } \\
\text { Away From Landfill }\end{array}$ \\
\hline Gbagada & 515 & 4 \\
\hline Olososun (Ojota) & 791 & 6 \\
\hline Abule Egba & 670 & 6 \\
\hline Solous (Igando) & 620 & 7 \\
\hline
\end{tabular}

\section{Statistical Analysis, 2010}

es. Journa 